\title{
Efficiency of using of the mineralized malts composition for the enhancement of food products by micronutrients
}

\author{
Alla Bashta ${ }^{1}$, Nadija Ivchuk ${ }^{1}$, Oleksandr Bashta ${ }^{2}$ \\ 1 - National University of Food Technologies, Kyiv, Ukraine \\ 2 - National Aviation University, Kyiv, Ukraine
}

Keywords:

Maize

Oat

Malt

Zinc

Chromium

Article history:

Received

20.09.2019

Received in revised

form 25.11.2019

Accepted

28.11.2019

\section{Corresponding}

author:

Alla Bashta

E-mail:

alla.sher.b@

gmail.com

\section{DOI:}

$10.24263 / 2310-$

$1008-2019-7-2-8$

\section{Abstract}

Introduction. The purpose of research is to obtain and investigate the composition of malts with high content of deficient micronutrients and enrichment with selected raw materials the rye-wheat bread.

Materials and methods. To obtain mineralized grain raw materials, maize and oat were germinated using solutions of zinc salt $(\mathrm{ZnSO} 4)$ and chromium one $\left(\mathrm{CrK}\left(\mathrm{SO}_{4}\right)_{2} \times 10 \mathrm{H}_{2} \mathrm{O}\right)$ of different concentrations: $0.001 \%, 0.002 \%, 0.003 \%, 0.004 \%$, and $0.005 \%$. X-ray fluorescence analysis was used to determine the mineral composition of grain and malt and stripping voltammetry method to determine the zinc content.

Results and discussion. The optimum concentration of zinc salt in soaking water equaled $0.002 \%$, at which the zinc content of the enriched maize increased by 6.7 times compared to the original grain. For the enrichment of grain with chromium ions, the chromium salt concentration in soaking water should not exceed $0.001 \%$.

According to the X-ray fluorescence analysis the mineral content in enriched malt is increasing, the content of zinc increased by 6 times in comparison with the original, and content of chromium by 3 times, that indicate the possibility of the source raw material mineral composition correcting by soaking and germinating grain in aqueous solutions of microelement salts.

To enrich the food products with mineralized malts, ryewheat bread was chosen as the traditional product in this work. Mineralized malts have a positive effect on the lifting power of yeast, and more so when zinc salts are added. This indicates a reduction in the duration of the technological process.

Studies of influence of the inserted mineralized malt's weight part on the quality indicators of rye-wheat bread showed that the optimal amount is the introduction of $10 \%$ by weight of flour.

Conclusions. The addition of such mineralized raw materials to food products formula will enrich them with biologically active substances gives them functional properties. 


\section{Introduction}

Functional food products based on fermented beverages are being developed most dynamically in the world market, and are based on fermented beverages and bakery products $[1,3,4,8,9,10]$.

Unlike many other products, bread products are able to provide the human body with a large amount of energy and almost all vital substances: proteins, carbohydrates, vitamins, minerals. Nutritional value of bread depends on the type and kind of flour, recipe additives and humidity of the product.

Compared to wheat flour products, rye bread differs favorably in the content of essential amino acids, minerals and vitamins. Therefore, having a lower energy value than wheat bread, it has a higher biological value, that is, it better provides the human body with the necessary substances $[11,12,13,14]$. Despite the high nutritional value, according to the modern requirements of the nutrition science, bread products need to improve their composition. Bread do not have the optimal ratio of proteins and carbohydrates, calcium and phosphorus, insufficient micronutrient content, essential amino acids such as lysine, methionine, tryptophan.

The enrichment of food products, in particular the bakery products with high micronutrient content, is an urgent task. It is known that deficiency of micronutrients, especially such as zinc, chromium, selenium and others, today there is an acute issue $[2,5$, $7,15,16,17,18]$. The deficiency of microelements reduces the body's resistance to various diseases, accelerates the aging process, increases the negative impact of adverse environmental conditions, and prevents the formation of a healthy generation $[6,19,20,21$, 22].

Systemic usage of malt stimulates metabolism and hematopoiesis, strengthens the immune system, compensates for vitamin and mineral deficiency, improves acid-base balance, and promotes intense digestion. When choosing malt composition, we were guided by the fact that the composition of these types of malt based on maize and oat makes it possible to exceed the shortage of certain valuable nutrients. Thus, vitamin $\mathrm{E}$ is found in maize malt in large quantities, while oat malt is rich in threonine and lysine, but lysine is deficient in wheat flour. Oat malt is especially valuable for its macro- and microelement content; while maize is the source of vitamins and the main raw material for the production of diet products.

It is known that it is expedient to carry out cereals mineralization by germination in the mineralized medium. Actually this method of grain processing that metal ions are incorporated into organic complexes that are easily digestible for the human body [23, 24, $25,26]$.

The microelements are actively involved in the enzymatic processes that take place in the grain, promote its growth and development and are important in the functioning of the human body. Chromium is important for the prevention of diabetes and cardiovascular disease; it also regulates carbohydrate metabolism and blood glucose. Zinc shows immunomodulatory, anti-inflammatory, antimicrobial, antioxidant functions. It affects the activity of hypophysiotropic hormones, participates in the implementation of insulin biological functions, normalizing fat metabolism, hematopoiesis, as well as necessary for normal functioning of the hypophysis and pancreas.

The purpose of research is to obtain and investigate the composition of malts with high content of deficient micronutrients and enrichment with selected raw materials the rye-wheat bread. 


\section{Materials and methods}

\section{Materials}

The subject of research is malt of cereals (maize and oat), salts of chromium and zinc, mineralized grain crop's malt, rye-wheat bread enriched with the composition of mineralized malts.

\section{Methods}

To obtain mineralized grain raw materials, maize and oat were germinated using solutions of zinc salt $(\mathrm{ZnSO} 4)$ and chromium one $\left(\mathrm{CrK}\left(\mathrm{SO}_{4}\right)_{2} \times 10 \mathrm{H}_{2} \mathrm{O}\right)$. Germination was carried out at a temperature of $17-18{ }^{\circ} \mathrm{C}$. When required humidity of the grain $(47 \%)$ reached, the soaking solution with salts was drained and the grain was left for germination, stirring and moistening it periodically with the same mineralized solutions.

In the process of raw materials, semi-finished products and finished product research there are used titrimetric, photocolorimetric, refractometric and sensory evaluation conventional methods of research [27]. X-ray fluorescence analysis was used to determine the mineral composition of grain and malt $[28,29]$ and stripping voltammetry method [27, 30] to determine the zinc content.

\section{Results and discussion}

\section{Obtaining and researching the composition of mineralized malts}

Current trends in consumption of products with reduced caloricity and increased nutritional value require innovative solutions in the process of creating a new range of bakery products. Vegetable raw materials with high nutritional and biological value include germinated grain products. The sprouted grain (malt) contains the entire set of ingredients needed for efficient nutrition: essential amino acids, carbohydrates (sugars, dextrins, dietary fiber), minerals, vitamins, dyes and polyphenolic compounds. The production of malt flour involves grain soaking, germination and drying.

To determine the zinc ions effect on the process of maltening of maize and oat grains there were used zinc sulfate solutions of different concentrations: $0.001,0.002,0.003,0.004$ and $0.005 \%$.

The results of studies of the zinc ions effect on the intensity of maize and oats germination are shown in Figure 1 and Figure 2 respectively.

The data shows that germination energy 13-14\% higher for oat and maize grains at $0.002 \%$ zinc salt concentration in comparison with pure water.

Zinc content of maize and maize malt was investigated by inversion voltammetry [27, 30]. With the chosen optimum concentration of $0.002 \%$ zinc salt in soaking water, it was determined that the zinc content of the enriched maize increased by 6.7 times compared to the original grain (Table 1). The zinc content of the grain does not exceed the maximum permissible concentration of $50 \mathrm{mg} / \mathrm{kg}$. 


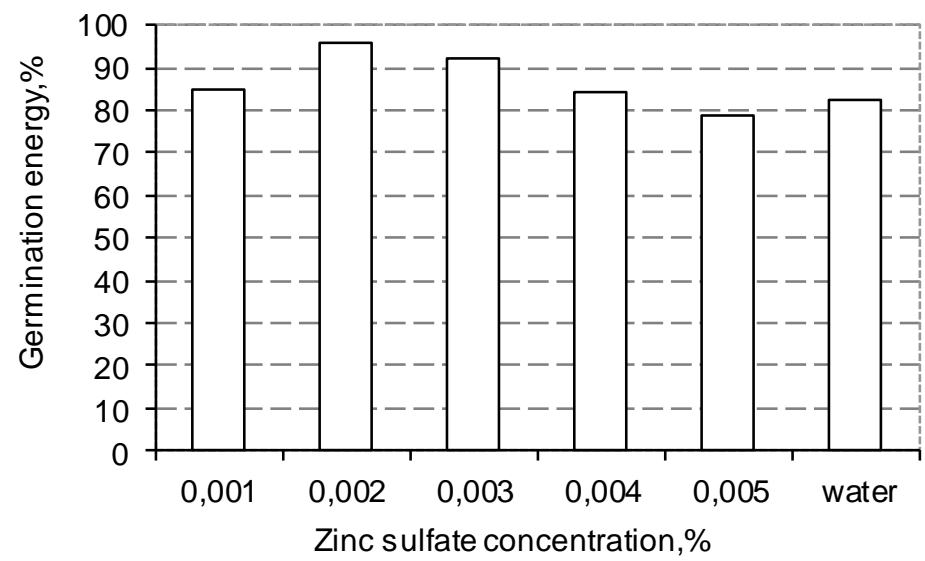

Figure 1. Investigation of zinc ions influence on the process of maize grain germination

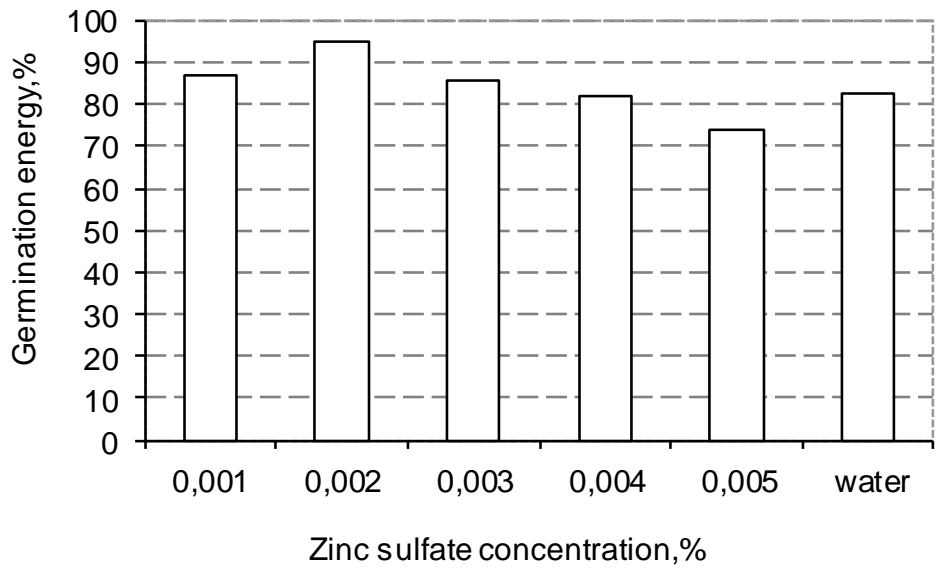

Figure 2. Investigation of zinc ions influence on the process of oat grain germination

Investigation of zinc accumulation in maize

Table 1

\begin{tabular}{|c|c|c|}
\hline \multirow{2}{*}{ Name of the mineral } & \multicolumn{2}{|c|}{ Mineral content, mg/kg } \\
\cline { 2 - 3 } & In the source grain & In the enriched grain \\
\hline Zinc & 1.7 & 11.4 \\
\hline
\end{tabular}


The germination of oat and maize grains was studied using different concentrations of the chromium salt solutions $\mathrm{CrK}\left(\mathrm{SO}_{4}\right)_{2} \cdot 10 \mathrm{H}_{2} \mathrm{O}$ (Figure 3 and Figure 4).

The figures show that the $0.001 \%$ chromium salt concentration in the soaking water leads to an increase of the grain germination energy at 12-13\% compared with the intensity of germination in water. With increasing concentrations of chromium salt in soaking water $(0.002-0.004 \%)$, the germination energy of maize and oat grains decreases. Therefore, for the enrichment of grain with chromium ions, the concentration of chromium salt in soaking water should not exceed $0.001 \%$.

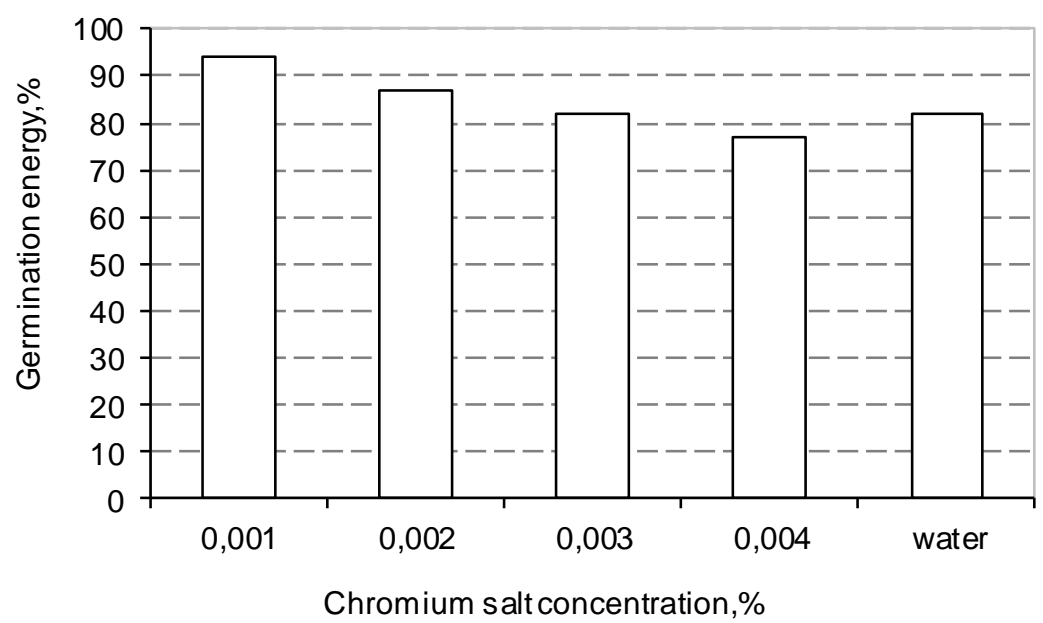

Figure 3. Investigation of chromium ions influence on the process of oat grain germination

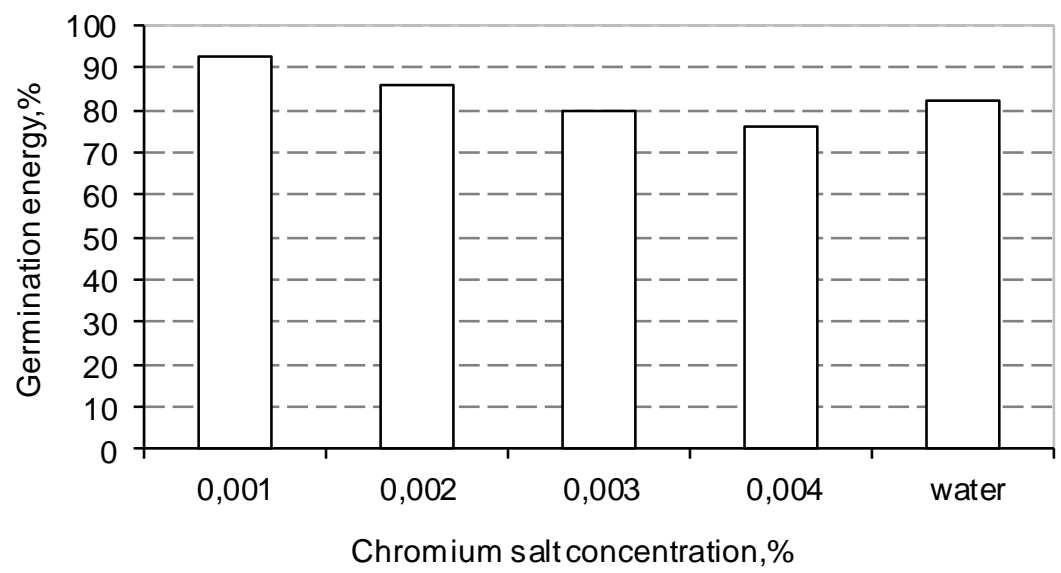

Figure 4. Investigation of chromium ions influence on the process of maize grain germination 
X-ray fluorescence analysis was used to study the mineral composition of oat grains and malt $[28,29,3130]$. According to the X-ray fluorescence characteristics of oat grain, oat malt and mineralized oat malt [31], the results of the mineral accumulation study are given in Table 2.

From the analysis of results, it follows that the mineral content is increasing, the content of zinc in enriched malt increased by 6 times in comparison with the original, and that of chromium by 3 times.

Thus, the conducted studies indicate the possibility of the source raw material mineral composition correcting by soaking and germinating grain in aqueous solutions of microelement salts. The addition of such mineralized raw materials to food products formula will enrich them with biologically active substances, giving them functional properties.

The sensory and physicochemical parameters of the obtained mineralized malt were determined. According to the results, the obtained malts are in accordance with all indicators of the normative documents.

Table 2

Mineral content in oat grains and malt when enriched with zinc and chromium salts

\begin{tabular}{|c|c|c|c|c|}
\hline \multirow{2}{*}{ Element } & Oatgrain & Oatmalt & $\begin{array}{c}\text { Mineralized with } \\
\text { zinc oat malt }\end{array}$ & $\begin{array}{c}\text { Mineralized with } \\
\text { chromium oat malt }\end{array}$ \\
\cline { 2 - 5 } & \multicolumn{4}{|c|}{ Massconcentration, mg/kg } \\
\hline $\mathrm{Zn}$ & 1.87 & 2.07 & 11.72 & 2.18 \\
\hline $\mathrm{Cr}$ & 0.19 & 0.71 & 0.67 & 2.25 \\
\hline $\mathrm{K}$ & 113.67 & 144.55 & 148.32 & 135.12 \\
\hline $\mathrm{Ca}$ & 56.60 & 60.49 & 66.40 & 59.72 \\
\hline $\mathrm{Mn}$ & 1.31 & 1.75 & 1.64 & 1.58 \\
\hline $\mathrm{Fe}$ & 2.27 & 2.49 & 2.55 & 2.48 \\
\hline $\mathrm{Cu}$ & 0.67 & 0.67 & 1.10 & 0.82 \\
\hline $\mathrm{S}$ & 374.15 & 497.30 & 430.33 & 490.35 \\
\hline $\mathrm{Cl}$ & 69.59 & 97.34 & 109.50 & 129.46 \\
\hline
\end{tabular}

\section{Enrichment with composition of mineralized malt of rye-wheat bread}

To enrich the food with mineralized malts, rye-wheat bread was chosen as the traditional product in this work. Bread is a food product made from flour of different grades with or without baker's yeast. Baker's yeast is adapted to live and grow in a water-flour environment. The bringing into the recipe of bread components that can adversely affect their vital activity is negatively affected on the technological process and quality of the finished product.

So far as selected minerals are active participants of biochemical processes in biological objects and they are active sites of enzymes, it was studied their effect on the activity of the fermentation microorganisms. The developed composition of the mineralized oat and maize malts (malts with a ratio of 1:1) in an amount of 5\% there are used. The optimal determined concentrations of zinc salts $(0.002 \%)$ and chromium salts $(0.001 \%)$ were used for mineralization. Control was sample with oat and maize malt composition without mineralization.

Experiments (Figure 5) show that mineralized malts have a positive effect on the lifting power of yeast, and more so when zinc salts are added. 
This is obviously due to the positive role of the studied metal ions in the activation of yeast cell enzymes, the accelerated synthesis of the cellular enzyme $\alpha$-glucosidase, which causes the decomposition of maltose to glucose, which is rapidly fermented by the yeast cell, and activates other enzymes of cytoplasm. Alcohol fermentation is intensified as a result of enzyme activation [32].

A positive effect of the mineralized malt flour fraction from maize and oat, enriched (malts with a ratio of 1:1) with zinc and chromium sulfates, on the lifting power of yeast was also found (Figure 6,7). Apparently, when proportion of malt flour increased the balls floating time is reduced as compared with the control. This indicates a reduction in the duration of the technological process.

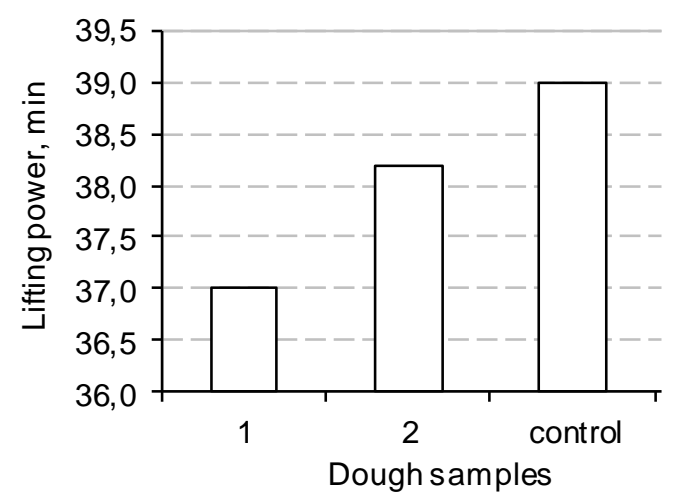

Figure 5. Dependence of baker's yeast lifting power on the addition of malt composition with zinc and chromium salts

1 - test sample with the addition of a malt composition with a zinc salt

in soaking water concentration of $0.002 \%$;

2 - test sample with the addition of a malt composition with a

chromium salt in soaking water concentration of $0.001 \%$;

Control - is a test sample with the addition of a malt composition

without the use of salts.

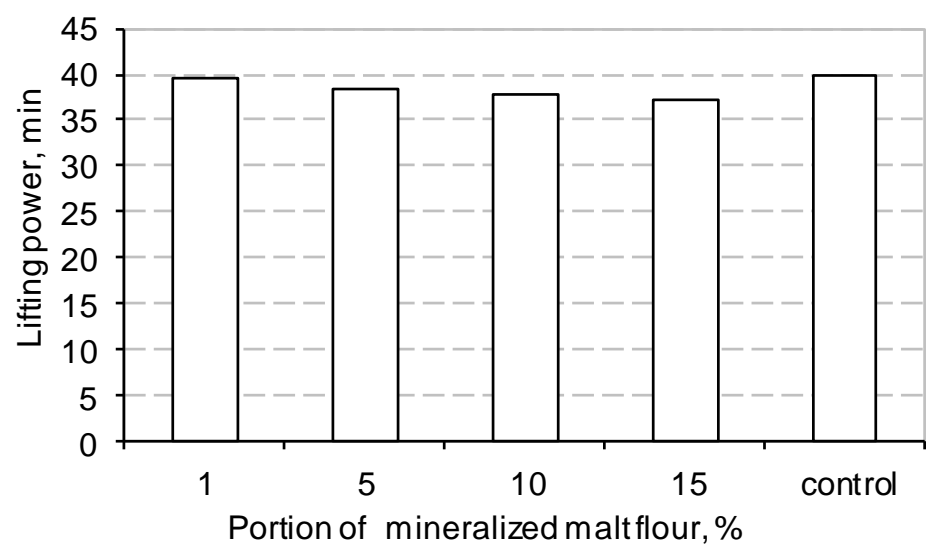

Figure 6. Determination the influence of the composition of malted maize flour with a zinc salt concentration of $0.002 \%$ on the yeast lifting power 


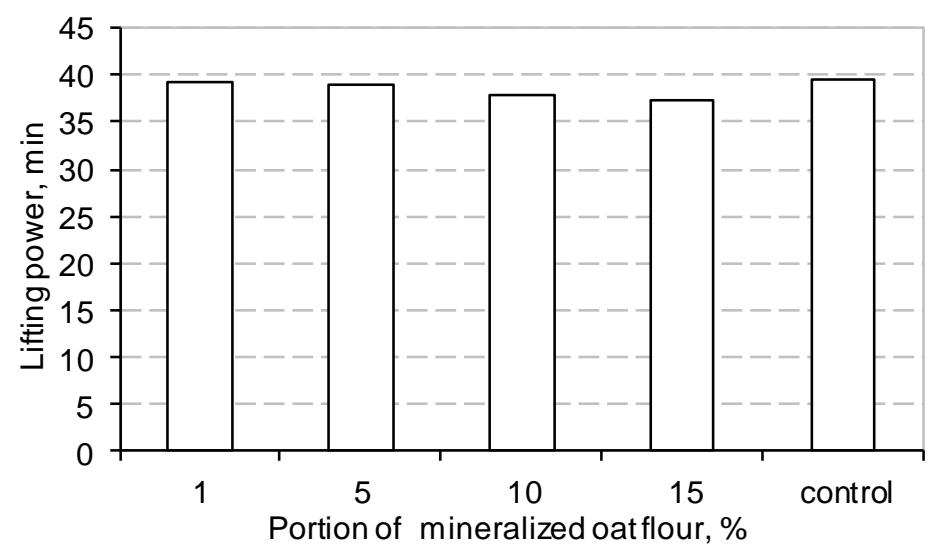

Figure 7. Determination the influence of the composition of malted oat flour with a chromium salt concentration of $0.001 \%$ on the yeast lifting power

The experiments of the bread samples baking were carried out to determine the optimal application dose of obtained mineral malts. Determined sensory and physico-chemical indicators of rye-wheat bread with the addition of $5 \%, 10 \%$ and $15 \%$ mineralized mixture of malts from oat grains and maize. The results are shown in the Table 3.

Studies of influence of the inserted mineralized malt's weight part on the quality indicators of rye-wheat bread showed that the optimal amount is the introduction of $10 \%$ by weight of flour, for which bread with satisfactory sensory and physico-chemical parameters is obtained.

The conceptual technological scheme of enriched bread with the stage of making the mixture of malt at the preparation of the ferment phase is developed. This will reduce the duration of fermentation and increase the biological value of the finished product.

The calculation method [33, 34, 35, 36] determined the content of macro- and micronutrients in rye-wheat bread before and after the introduction of mineralized malt in the amount of $10 \%$ by flour weight. It is found that enriched bread increases the protein content by $21 \%$, it is possible to increase the content of such essential deficient amino acids as lysine and methionine, and accordingly improve the utilization coefficient, which shows the level of protein absorption of the product.Thus, the utilization coefficient was $63.8 \%$ in the enriched product and 59\% in the base product.That is, by adding of selected enrichment protein digestibility increased, with the coefficient of excess amino acid composition, which characterizes the mass fraction of indispensable amino acids and used in the body irrationally, decreased to $12.5 \%$. The goal of the micronutrients content increasing in the enriched finished product, including the microelements $\mathrm{Zn}$ and $\mathrm{Cr}$ by 2.4 and 1.8 times respectively, was also achieved. 
Table 3

Sensory and physico-chemical indicators of rye-wheat bread with the addition of mineralized mixture of malts from oats grain and maize (malts with a ratio of 1:1)

\begin{tabular}{|c|c|c|c|c|}
\hline Indicators & $\begin{array}{c}\text { Control } \\
\text { (rye- } \\
\text { wheatbread) }\end{array}$ & $\begin{array}{c}\text { Rye-wheat } \\
\text { bread with } \\
5 \% \text { mixture of } \\
\text { malts } \\
\end{array}$ & $\begin{array}{l}\text { Rye-wheat } \\
\text { bread with } \\
10 \% \text { mixture } \\
\text { of malts }\end{array}$ & $\begin{array}{c}\text { Rye-wheat } \\
\text { bread with } \\
15 \% \text { mixture } \\
\text { of malts }\end{array}$ \\
\hline \multicolumn{5}{|c|}{ Sensoryindicators } \\
\hline $\begin{array}{c}\text { Appearance: } \\
\text { Form } \\
\text { Surface }\end{array}$ & $\begin{array}{l}\text { Proper shape, } \\
\text { without tears } \\
\text { or cracks }\end{array}$ & $\begin{array}{l}\text { Proper shape, } \\
\text { without tears } \\
\text { or cracks }\end{array}$ & $\begin{array}{l}\text { Proper shape, } \\
\text { without tears } \\
\text { or cracks }\end{array}$ & $\begin{array}{l}\text { Proper shape, } \\
\text { there are small } \\
\text { cracks in the } \\
\text { crust }\end{array}$ \\
\hline Crumbcolor & Brown & Brown & Brown & Brown \\
\hline Crumbcondition & $\begin{array}{c}\text { Baked, with no } \\
\text { trace of } \\
\text { undermixing; } \\
\text { homogeneous, } \\
\text { with well- } \\
\text { developed } \\
\text { porosity }\end{array}$ & $\begin{array}{l}\text { Homogeneous, } \\
\text { with well- } \\
\text { developed } \\
\text { porosity }\end{array}$ & $\begin{array}{l}\text { Homogeneous, } \\
\text { with well- } \\
\text { developed } \\
\text { porosity }\end{array}$ & $\begin{array}{c}\text { Homogeneous, } \\
\text { poorly } \\
\text { developed } \\
\text { porosity, } \\
\text { slightly } \\
\text { compacted }\end{array}$ \\
\hline Tasteandsmell & $\begin{array}{c}\text { Inherent to this } \\
\text { type of } \\
\text { products, } \\
\text { without any } \\
\text { foreign taste }\end{array}$ & $\begin{array}{c}\text { Inherent to this } \\
\text { type of } \\
\text { products, } \\
\text { without any } \\
\text { foreign taste }\end{array}$ & $\begin{array}{c}\text { Inherent to this } \\
\text { type of } \\
\text { products }\end{array}$ & $\begin{array}{l}\text { Inherent to this } \\
\text { type of } \\
\text { products, with } \\
\text { a noticeable } \\
\text { taste of malt }\end{array}$ \\
\hline \multicolumn{5}{|c|}{ Physico-chemicalindicators } \\
\hline $\begin{array}{c}\text { Specificvolume, } \\
\mathrm{cm} 3 / \mathrm{g}\end{array}$ & 1.92 & 1.87 & 1.83 & 1.77 \\
\hline Humidity, $\%$ & 45.4 & 45.5 & 45.6 & 46.0 \\
\hline Acidity, deg & 6.4 & 6.5 & 6.6 & 6.7 \\
\hline Porosity, $\%$ & 67 & 65 & 64 & 62 \\
\hline
\end{tabular}

\section{Conclusions}

As a result of grain germination, the content of biologically active substances is increased. The germination of grain in a mineralized environment also contributes to the accumulation of minerals in it. Studies have shown that the use of mineralized malt composition in bread technology is expedient, since it contributes to a significant improvement in the content of physiologically active ingredients which provide the health properties of bread.

\section{References}

1. Simakhina H.O., Naumenko N.V. (2018), Tendentsiirozvytkukharchovoipromyslovosti tekhnolohiiproduktivdliazdorovohokharchuvannia, Prospects for Ukraine and Poland : international Multidisciplinary Conference, 3, pp. 96-100. 
2. Simakhina, H. (2014), Ozdorovchiprodukty yak realizatsiianovoikontseptsiikharchuvannia, Ozdorovchikharchoviprodukty ta diietychnidobavky: tekhnolohii, yakist ta bezpeka: MaterialyMizhnarodnoinaukovo-praktychnoikonferentsii, pp. 11-12.

3. Lozano-Baena M.-D., Tasset I., Muñoz-Serrano A., Alonso-Moraga Á., de Haro-Bailón A. (2016), Cancer prevention and health benefices of traditionally consumed BoragoOfficinalis plants, Nutrients, 8(1), p. 48.

4. $\quad$ Ortega R.M., Jiménez Ortega A.I., Perea Sánchez J.M., MartínezGarcía R.M., LópezSobaler A.M., (2017), Oral feeding and nutritional improvement in hospitals and residential care homes. Industry innovations | [Alimentación oral en la mejoranutricionalenhospitales y residencias. Innovacionesdelaindustria], Nutricionhospitalaria, 34, pp. 13-18.

5. Simakhina H.O., Stetsenko N.O., NaumenkoR.Yu. (2018), Naukoveobgruntuvanniavyborunutriientiv, adekvatnykhpotrebamliudyny, Proceedings of XXXVII International scientific conference «Scientific look at the present», pp. 9-12.

6. Sirasa F., Mitchell L.J., Rigby R., Harris N. (2019), Family and community factors shaping the eating behaviour of preschool-aged children in low and middle-income countries: A systematic review of interventions, Preventive Medicine, 129, Article number 105827.

7. Baugreet S., Hamill R.M., Kerry J.P., McCarthy S.N. (2017), Mitigating Nutrition and Health Deficiencies in Older Adults: A Role for Food Innovation, Journal of Food Science, 82(4), pp. 848-855.

8. Maryati Y., Susilowati A. (2018), Fermentation of pitaya (Hylocereuspolyrhizus) juice by L. acidophilus in metabolism of sugars for cholesterol removal, AIP Conference Proceedings, 2026, Article number 020064.

9. Angelov A., Yaneva-Marinova T., Gotcheva V. (2018), Oats as a matrix of choice for developing fermented functional beverages, Journal of Food Science and Technology, 55(7), pp. 2351-2360.

10. Khurana H.K., Kanawjia S.K. (2007), Recent trends in development of fermented milks, Current Nutrition and Food Science, 3(1), pp. 91-108.

11. Yaver E., Bilgiçli N., (2018), Utilisation of cereal-legume flour blends in commercial and traditional bread, Quality Assurance and Safety of Crops and Foods, 10(3), pp. 297-306.

12. Wu T., Taylor C., Nebl T., Ng K., Bennett L.E. (2017), Effects of chemical composition and baking on in vitro digestibility of proteins in breads made from selected gluten-containing and gluten-free flours, Food Chemistry, 233, pp. 514-524.

13. Jonsson K., Andersson R., Bach Knudsen K.E., Tjønneland A., Landberg R. (2018), Rye and health - Where do we stand and where do we go?,Trends in Food Science and Technology, 79, pp. 78-87.

14. Makhynko V.M., Makhynko V.M. (2010), Normyspozhyvanniakhliba v riznykhkrainakh z pohliaduzadovolenniaosnovnykhpotreborhanizmu,

KhlibopekarskaikondyterskapromyslovistUkrainy, 6, pp. 8 - 11 .

15. Palanog A.D., Calayugan M.I.C., Descalsota-Empleo G.I., et al. (2019), Zinc and iron nutrition status in the philippines population and local soils, Frontiers in Nutrition 6, pp. 81.

16. Aziz M.Z., Yaseen M., Abbas T., et al. (2019), Foliar application of micronutrients enhances crop stand, yield and the biofortification essential for human health of different wheat cultivars, Journal of Integrative Agriculture 18(6), pp. 1369-1378.

17. Meng L., Wang Y., Li T., Loo-Bouwman C.A.V., Zhang Y., Man-Yau Szeto I. (2018), Dietary Diversity and Food Variety in Chinese Children Aged 3-17 Years: Are They Negatively Associated with Dietary Micronutrient Inadequacy?, Nutrients, 10(11).

18. Beintema J.J.S., Gallego-Castillo S., Londoño-Hernandez L.F., Restrepo-Manjarres J., Talsma E.F. (2018), Scaling-up biofortified beans high in iron and zinc through the school-feeding program: A sensory acceptance study with schoolchildren from two departments in southwest Colombia, Food Science and Nutrition, 6(4), pp. 1138-1145.

19. King C. (2018), Food insecurity and child behavior problems in fragile families, Economics and Human Biology,28, pp. 14-22.

20. Wang X., Hui Z., Dai X., Terry P.D., et al. (2017), Micronutrient-fortified milk and academic performance among Chinese middle school students: A cluster-randomized controlled trial, Nutrients, 9(3), art. no. 226. 
21. Hombali A.S., Solon J.A., Venkatesh B.T., Nair N.S., Peña-Rosas J.P. (2019), Fortification of staple foods with vitamin a for vitamin a deficiency, Cochrane Database of Systematic Reviews,(5), CD010068.

22. Kehoe S.H., Dhurde V., Bhaise S., et al. (2019), Barriers and Facilitators to Fruit and Vegetable Consumption Among Rural Indian Women of Reproductive Age, Food and Nutrition Bulletin, 40(1), pp. 87-98.

23. Simakhina H.O., Korykhalova O.M., Mykoliv T.I. (2011), Teoretychni ta praktychniaspektyzbahachenniazernovykhkulturesentsialnymymikroelementamy, Tovaroznavstvo ta innovatsii, 3, pp. 272-281.

24. Simakhina G.A., Bazhay-Zhezherun S.A., Mykoliv T.I., Bereza-Kindzerska L.V., Antoniuk M.M. (2016), The Use Of The Biologically Activated Grain Is In Technology Of Health Products, East European Scientific Journal, 5(9), 4, pp.147-153.

25. Simakhina G., Fedorenko T. (2016), Perspectives of designing the compositional mixtures from cereal cultures, Proceedings of 8th Central European Congress on Food "Food for Well-Being", pp. 66 .

26. Simakhina G.O. (2013), Tekhnolohichni aspekty pidvyshchennia biodostupnosti osnovnykh funktsionalnykh nutriientiv, NaukovipratsiNUKhT, 50, pp. 16-23.

27. Mendoza S., Bustos E., Manríquez J., Godínez L.A. (2015), Agricultural and Food Electroanalysis, Wiley Blackwell, Mexico.

28. Mir-Marqués A., Garrigues S., Cervera M.L., De la Guardia M. (2014), Direct determination of minerals in human diets by infrared spectroscopy and X-ray fluorescence, Microchemical Journal, 117, pp. 156-163.

29. Paltridge N.G., Milham P.J., Ortiz-Monasterio J.I., Velu G., et al. (2012), Energy-dispersive Xray fluorescence spectrometry as a tool for zinc, iron and selenium analysis in whole grain wheat, Plant and Soil, 361(1-2), pp. 261-269.

30. Feier B., Floner D., Cristea C., Bodoki E., Sandulescu R., Geneste F. (2012), Flow electrochemical analyses of zinc by stripping voltammetry on graphite felt electrode, Talanta, 98 , pp. $152-156$.

31. Bashta A.O., Ivchuk N.P., HoikoI.Yu., Polishchuk M.B. (2018), Otrymannia ta doslidzhennia skladu mineralizovanykh solodiv, Zbirnykmaterialiv XIV Mizhnarodnoikonferentsii «Stratehiiayakosti u promyslovostiiosviti», 1, pp. 19-24.

32. Semenchuk S., Simonovets I., Drobot V., Holinko I. (2014), Zbahachennia khliba mahniiem ta tsynkom, Naukovi zdobutky molodi - vyrishenniu problem kharchuvannia liudstva u XXI stolitti: prohrama $i$ materialy 80 mizhnarodnoi naukovoi konferentsii molodykh uchenykh, aspirantiv $i$ studentiv, Ch. 1, pp. 180-181.

33. World Health Organization (WHO) (2007), Protein and amino acid requirements in human nutrition: report of a Joint FAO/WHO/UNU Expert Consultation (WHO technical report series), 935. Available at: http://apps.who.int/iris/bitstream/10665/43411/1/WHO_TRS_935_eng.pdf.

34. Ponomareva E.I., Alekhina N.N., Bakaeva I.A. (2016), Bread from the bioactivated wheat grain with the raised nutrition value, VoprosyPitaniia, 85(2), pp. 116-121.

35. Food and Agriculture Organization (FAO) (2013), Dietary protein quality evaluation in human nutrition: report of an FAO Expert Consultation, Available at: http://www.fao.org/3/a-i3124e.pdf.

36. Borisenko A.A., Kas'janov G.L., Zaporozhskij A.A. (2005), Proektirovanie sbalansirovannyh polikomponentnyh pishhevyh produktov na osnove ih nutrientno gosostava, Izvestija vuzov. Pishhevaja tehnologija, 2-3, pp. 106-107. 